\title{
Treatment of Total Limbal Stem Cell Deficiency With Autologous Ex Vivo Cultivated Limbal Epithelial Stem Cell Graft
}

\author{
Iva Dekaris ${ }^{1,2}$ (D), Mirna Tominac-Trcin ${ }^{3}$, Doria Gabrić ${ }^{1}$ \\ 'Special Eye Hospital 'Svjetlost', Zagreb Croatia \\ ${ }^{2}$ Department of Ophthalmology of University of Rijeka, Rijeka, Croatia \\ ${ }^{3}$ Tissue Bank, University Department of Traumatology, University Hospital Centre «Sestre Milosrdnice», Zagreb, Croatia
}

OPEN ACCESS

Correspondence:

Prof. Iva Dekaris, MD PhD iva.svjetlost@gmail.com orcid.org/0000-0003-4133-9783

This article was submitted to RAD CASA - Medical Sciences as the original article

Conflict of Interest Statement: The authors declare that the research was conducted in the absence of any commercial or financial relationships that could be construed as a potential conflict of interest.

Received: 17 June 2019 Accepted: 24 June 2019 Published: 22 July 2019

Citation: Dekaris I, Tominac-Trcin M and Gabric D. Treatment of Total Limbal Stem Cell Deficiency with Autologous Ex Vivo Cultivated Limbal Epithelia Stem Cell Graft. RAD CASA - Medical Sciences. 537=46-47 (2019): 3-8 DOI: $10.21857 / \mathrm{yl} 4 \mathrm{okf} 3 \mathrm{ql}$

Copyright (C) 2019 Dekaris, Tominac-Trcin and Gabric. This is an open-access article distributed under the terms of the Creative Commons Attribution License (CC BY). The use, distribution or reproduction in other forums is permitted, provided the original author(s) and the copyright owners(s) are credited and that the original publication in this journal is cited, in accordance whit accepted cited, in accordance whit accepted adacemic practice. No use, distriwhich does not comply with these

\section{ABSTRACT:}

Limbal epithelial stem cell (LSC) deficiency is severe disease of the anterior eye surface, causing corneal opacification and significant vision loss in the affected patients. Treatment of such patients by corneal graft is ineffective due to the fact that corneal donor tissue cannot survive in the eye without LSC. One of possible treatment options is to provide LSC from the other, unaffected eye, and to perform corneal graft later on, as a second procedure. In this paper, we have evaluated the visual outcome and clinical improvement in three eyes receiving ex vivo cultivated limbal epithelial stem cell graft to treat their limbal stem cell deficiency (LSCD) caused by corneal burn. We aimed at determining whether this treatment alone might provide sufficient visual improvement to avoid corneal grafting as a second surgery.

KEYWORDS: corneal burn, limbal stem cell deficiency, ex vivo cultivation of limbal stem cells, corneal transplantation

\section{SAŽETAK:}

Nedostatak limbalnih matičnih stanica rožnice je teška bolest prednje površine oka koja uzrokuje značajan pad vida radi zamučenja rožnicw. Liječenje takovih bolesnika transplantacijom rožnice nije moguće jer donorsko rožnično tkivo ne može preživjeti ukoliko nema limbalnih matičnih stanica rožnice koje su zadužene za obnovu epitela rožnice. Mogućnost liječenja takvih bolesnika sastoji se u tome da se prvo obnove limbalne matične stanice presadbom stanica sa kontralateralnog zdravog oka, a kasnije kao sekundarna kirurška procedura može se učiniti transplantacija rožnice. U ovom radu istraživali smo oporavak vida i kliničko poboljšanje u tri bolesnika sa opekotinama prednje površine oka koji su radi nedostatka limbalnih matičnih stanica rožnice primili presadak ex vivo uzgojenih limbalnih stanica koje su kultivirane iz uzorka dobivenog sa njihovog drugog, zdravog oka. Želja nam je bila ustvrditi dali sama presadba matičnih stanica može dovesti do dovoljnog oporavka vida i prednje površine oka kako drugi zahvat, transplantacija rožnice, nebi niti bio potreban.

KLJUČNE RIJEČI: opekotina rožnice, nedostatak limbalnih matičnih stanica rožnice, ex vivo kultivacija limbalnih stanica, transplantacija rožnice 


\section{INTRODUCTION}

According to the World Health Organization, corneal blindness is the fourth leading cause of blindness globally. The impact of corneal blindness is huge, since it tends to affect younger people. Corneal transplantation may restore vision in many corneal diseases, however in case of corneal burns in which limbal epithelial stem cells (LSC) are destroyed corneal transplantation is not feasible. Only renewal of the corneal epithelium, through replacement of the limbal epithelial stem cell population may bring long term visual improvement. LSCs are situated at the corneo-scleral junction in an area known as the limbus. They share common features with other adult somatic stem cells including small size, high nuclear to cytoplasmic ratio, high proliferative potential, clonogenicity, multipotency, expression of stem cell markers such as p63; but lacking expression of differentiation markers such as cytokeratin 3 and 12. The transcription factor p63 is required for formation of epidermis and has been proposed as a putative positive LSC marker ${ }^{1}$.

Limbal epithelial stem cell deficiency (LSCD) most often occurs due to the corneal burn caused by alkali or acid injury of the anterior eye surface. Dependent on the severity of injury, only partial or total LSCD may happen. Total LSCD is clinically characterized by growth of conjunctival tissue over the cornea, corneal neovascularization and opacification. For centuries, patients with total LSCD caused by corneal burns were untreatable. Then a surgical approach was applied in which a grafting of limbal auto- or allo-graft was done combined with corneal grafting to supply a source of LSC $^{2,3}$. In such cases a larger amount of tissue had to be collected either from a contralateral healthy eye, thus carrying a risk of damage to healthy eye; or, if LSC graft was provided from allogenic tissue a risk from side effects of longterm immunosuppression was present ${ }^{4-6}$. Two decades ago, first results of successful cultivation of smaller sample of LSC harvested from the contralateral healthy eye and amplified in number by ex vivo cultivation, followed by their transplantation in human eye were reported ${ }^{7-9}$. Since that time different carriers for LSC cultivation have been tried in vitro, and their efficacy was tested in a clinical setting $5,10,11$.

\section{Materials AND METHOdS}

Two patients with total, and one patient with partial LSCD were included in the study. Samples of LSC for ex vivo cultivation were obtained from a $1 \mathrm{~mm}^{2}$ biopsy taken from the limbus of the contralateral healthy eye under topical anaesthesia.

\section{Cultivation of LSC}

All procedures regarding preparation of amniotic membrane as a carrier for LSC and cell cultures were made in aseptic conditions of clean room facility for cell cultures (class A and B of air cleanness). Amniotic membranes were prepared from human placenta obtained from healthy woman during caesarean section, according to established procedure ${ }^{12}$. After disinfection with
5\% ABAM solution and DPBS, each sample was incubated in $0.05 \%$ enzyme trypsin/1mM EDTA solution. Human limbal cells are counted and seeded in 2:1 ratio to previously prepared mice fibroblast nutrient layer. Media is changed every third day till $80 \%$ confluence, when cells are counted. Cell cultures are regularly monitored by optical microscopy for their viability. Immunocytochemical method and confocal microscopy is used to test cells for the presence of stem-cell marker p63 and differentiation marker cytokeratin $3^{13}$.

Clinical application of ex vivo expanded epithelial cells After LSC cultivation, and once the appropriate number and percentage of p63 positive cells is achieved ex vivo, LSC on amniotic membrane as a carrier were transferred to corneal surgeon for clinical application. Surgeries were done under local anaesthesia. Limbal peritomy was performed and fibrovascular pannus was carefully dissected from the cornea in all $360^{\circ}$. The amniotic-membrane carrying cultivated LSC were then gently placed on the prepared corneal bed with LSC facing toward the cornea. Perilimbal region of 3-4 mm bare sclera is also covered with LSC sheet and the border of the amniotic membrane is sutured to the adjacent conjunctiva with resorptive 8.0 suture. The eyelids were kept closed for one week. Post-operatively, patients received 2 -week systemic treatment with amoxicillin (500 mg tid) and 1 -month systemic prednisone $(24 \mathrm{mg})$ and ranitidine with gradual decrease of dosage. Topical steroid and antibiotic drops, and frequent artificial drops are started at day 14 after surgery, to prevent damage to the graft with lid manipulation. Throughout the postoperative follow-up, operated eyes were controlled for the regular epithelialization, decrease of corneal neovascularization and improvement of vision. Once the ocular surface becomes regular, improvement of vision was tested in order to determine whether patient is cured by LSC alone or second surgery - corneal transplantation (CT) is needed.

\section{RESULTS}

The preoperative clinical appearance of the eyes treated for limbal stem cell deficiency is represented in Figure 1. From their contralateral eye LSC samples were taken for ex vivo cultivation. Limbal stem cells cultured ex vivo fully covered their carrier, the amniotic membrane, between 10 to 14 days after the beginning of cultivation process. Testing of their quantity, morphology and viability was performed by optical microscopy; the uniform layer of stem cells is represented in Figure 2. To check whether cultivated cells are indeed stem cells, the presence and quantity of LSC differentiation marker p63 was measured. In Figure 3. immunofluorescence analysis of p63 and cytokeratin 3 (CK3) markers on cells cultured on fibrin, intact amniotic membrane and denuded amniotic membrane are represented. Expression of stem cell marker p63, and lacking expression of differentiation marker CK3 proved that the cultured cells were LSC and such cells were issued to surgeon for clinical application.

Patients with LSCD received LSC auto-graft cultivated ex vivo 

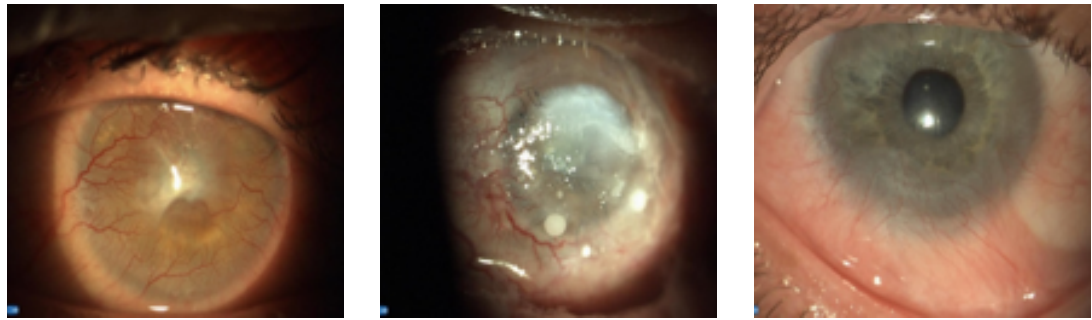

Figure 1. Appearance of the eyes with limbal epithelial stem cell deficiency caused by corneal burn.

and the clinical outcome regarding regeneration of their anterior surface and visual improvement was tested. As shown in Figure 4, patient with total LSCD caused by tear gas burn reached post-

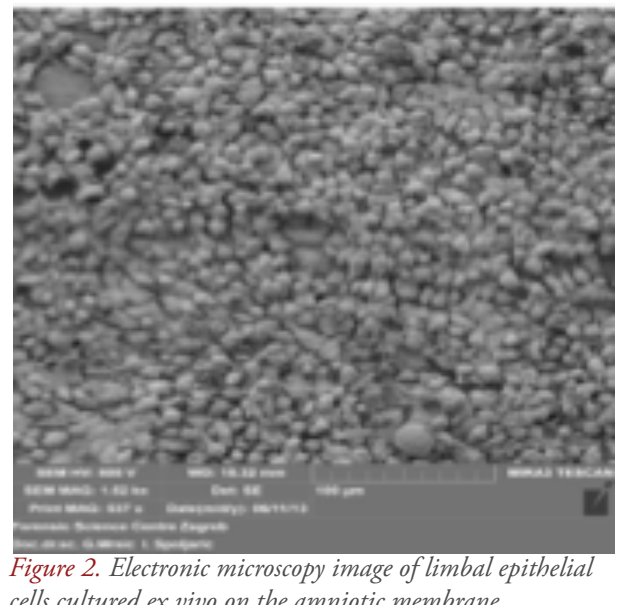

cells cultured ex vivo on the amniotic membrane.

operative visual acuity of $60 \%$ at 6-months after surgery, increasing to $100 \%$ vision at 1 postoperative year. His cornea became completely transparent and epithelialized with tiny vessels at the limbus of the cornea and remained stable for 2 postoperative years. Patient with partial LSCD caused by alkali burn obtained postoperative vision of $55 \%$ at 6 and $85 \%$ at 1 year, with normal appearance of the anterior eye segment (Figure 5). Only in one case with total LSCD caused by explosive wound, grafted limbal stem cells did not provide significant visual recovery (from light perception preoperatively to $10 \%$ postoperatively at 1 postoperative year); and clearance of the cornea was not fully achieved due to the fact that the patient had completely abnormal lid function causing constant inflammation and abnormal tear film at the anterior eye segment (Figure 6).

\section{DissCusion}

In case of LSC deficiency normal corneal epithelial homeostasis is disrupted and this may occur as a result of primary or acquired insults. Deficiency of the LSC may be partial or total ${ }^{14,15}$. The leading cause of total LSC deficiency are corneal burns with chemical or thermal substances and corneal diseases such as aniridia and Stevens Johnson syndrome. As a result of LSCD, conjunctivalization, neovascularisation, chronic inflammation, recurrent erosions, ulceration and stromal scarring can occur causing painful vision loss ${ }^{2,16}$. Conventional corneal transplantation has been unsuccessfully tried in such cases, since donor cornea cannot survive in a "milieu" where no LSC are present. First successful attempt to grow ocular surface epithelial cells in a culture for consequent use as grafts, was made in a mice model 17-19. Twenty years ago, Pellegrini et al. have reported first successful epithelialization of a burned human cornea treated with a novel approach - transplantation of ex vivo expanded LSC. Normal corneal differentiation in vitro was tested with a specific biochemical marker, and then the cells were grafted onto the burned eye. Successful re-epithelialization of the corneal surface

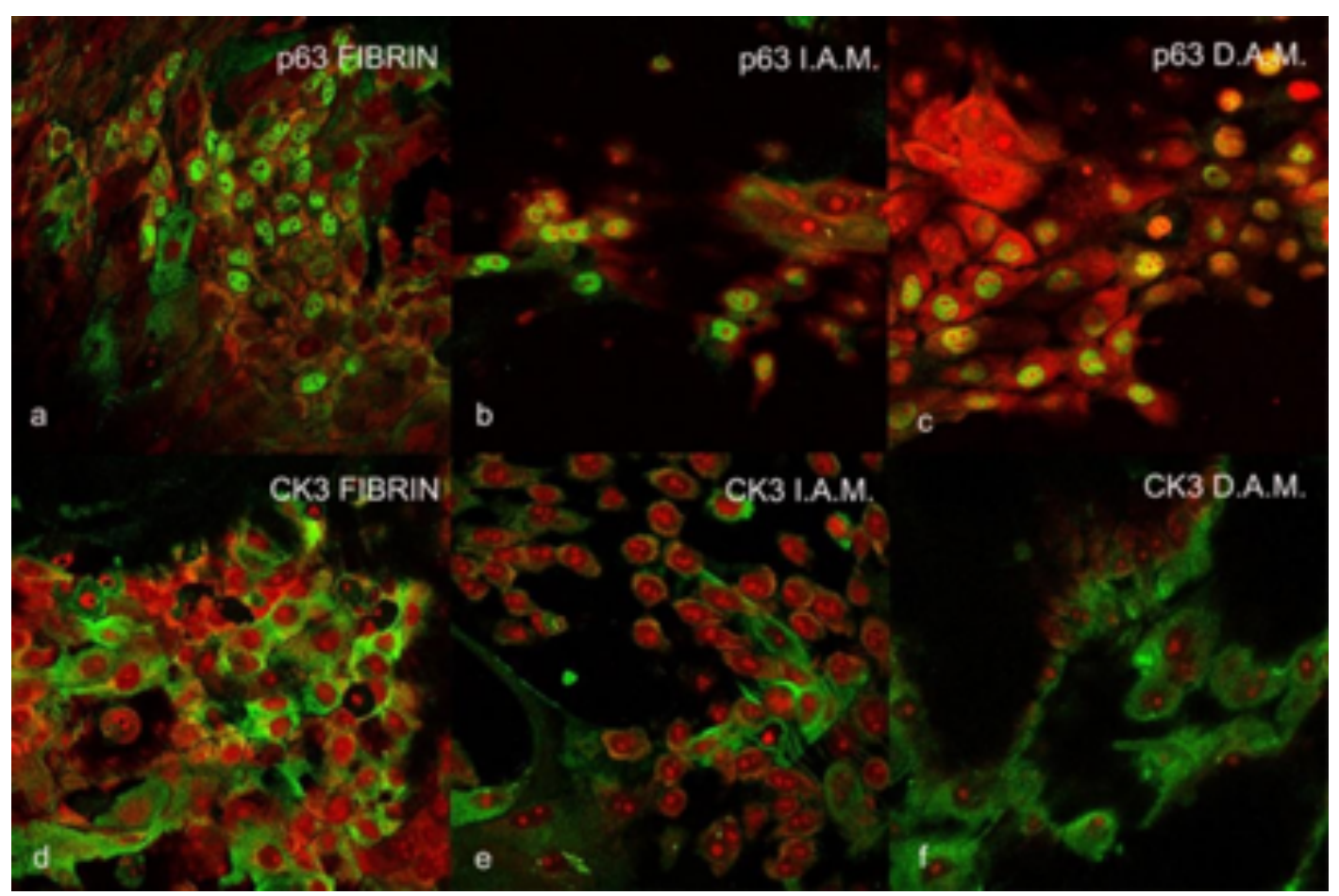

Figure 3. Immunofluorescence analysis of $p 63(a, b, c)$ and $C K 3(d, e, f)$ markers of limbal epithelial stem cells and differentiated limbal cells, cultured on fibrin $(a, d)$, intact amniotic membrane (I.A.M.) (b, e) and denuded amniotic membrane (D.A.M.) (c, f) respectively. was achieved in a 2 -year follow-up ${ }^{7,8}$. These results provided a new perspective on the treatment of ocular disorders characterised by stem-cell deficiency. Cultured LSC therapy has been further developed by several investigators using different protocols and carriers mostly amniotic membrane or fibrin, in the presence or absence of growth arrested 3T3 fibroblast feeder layers ${ }^{20,21}$. After those first findings many groups around the globe have continued to treat patients with LSC deficiency with ex vivo expanded limbal stem cells on different carriers such as amniotic membrane, fibrin or contact lens ${ }^{22-25}$. The most widely used ones in 

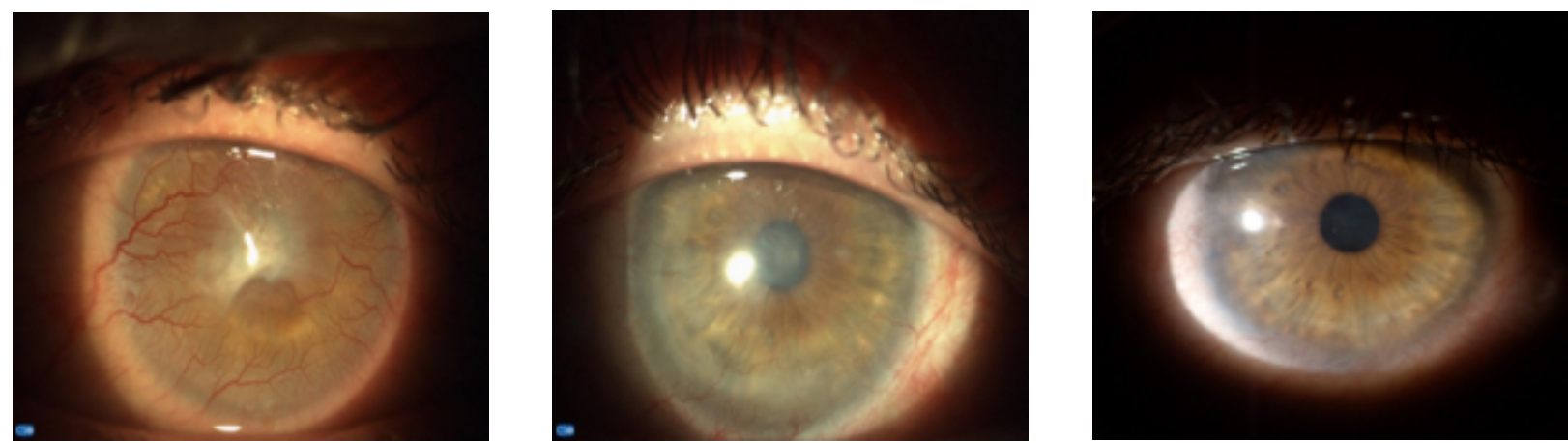

Figure 4. Preoperative image of an eye with total limbal stem cell deficiency caused by tear gas burn (upper left); and postoperative image at 1 year (upper right) and 2 years (lower left) after transplantation of ex vivo cultivated limbal epithelial stem cells. Visual acuity improved from preoperative value of light perception to $100 \%$ postoperatively.
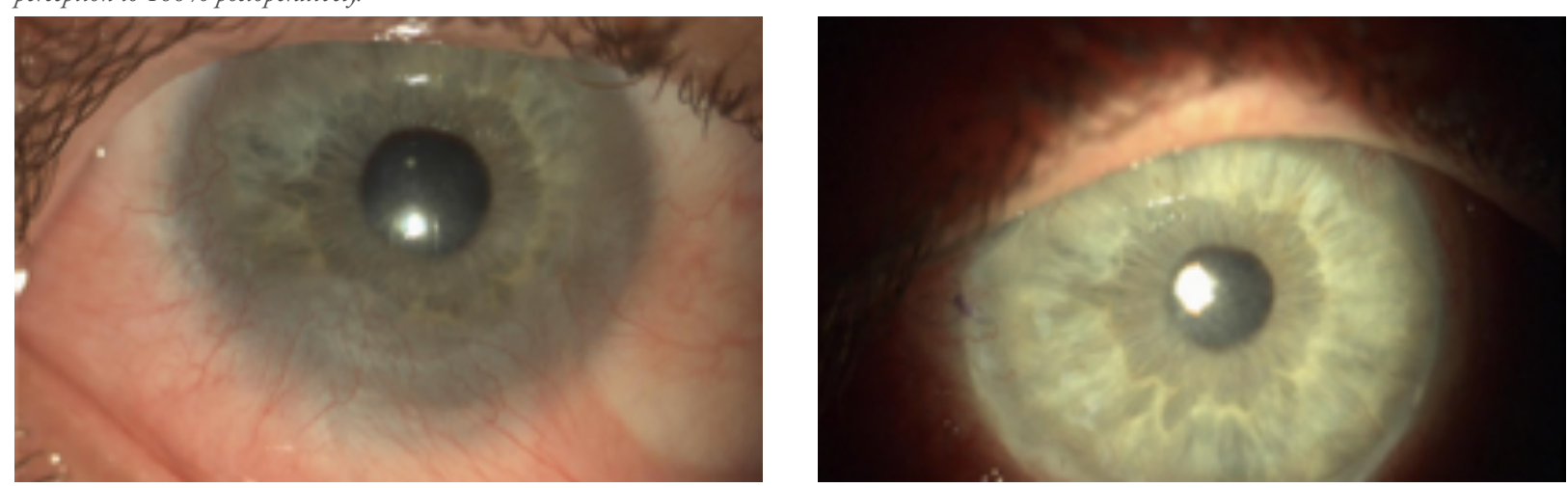

Figure 5. Preoperative image of an eye with partial limbal stem cell deficiency caused by alkali burn, and lyear postoperative appearance of the eye treated with ex vivo cultivated limbal epithelial stem cells. Visual acuity improved from preoperative value of $15 \%$ to $85 \%$ at 1 year postoperatively.
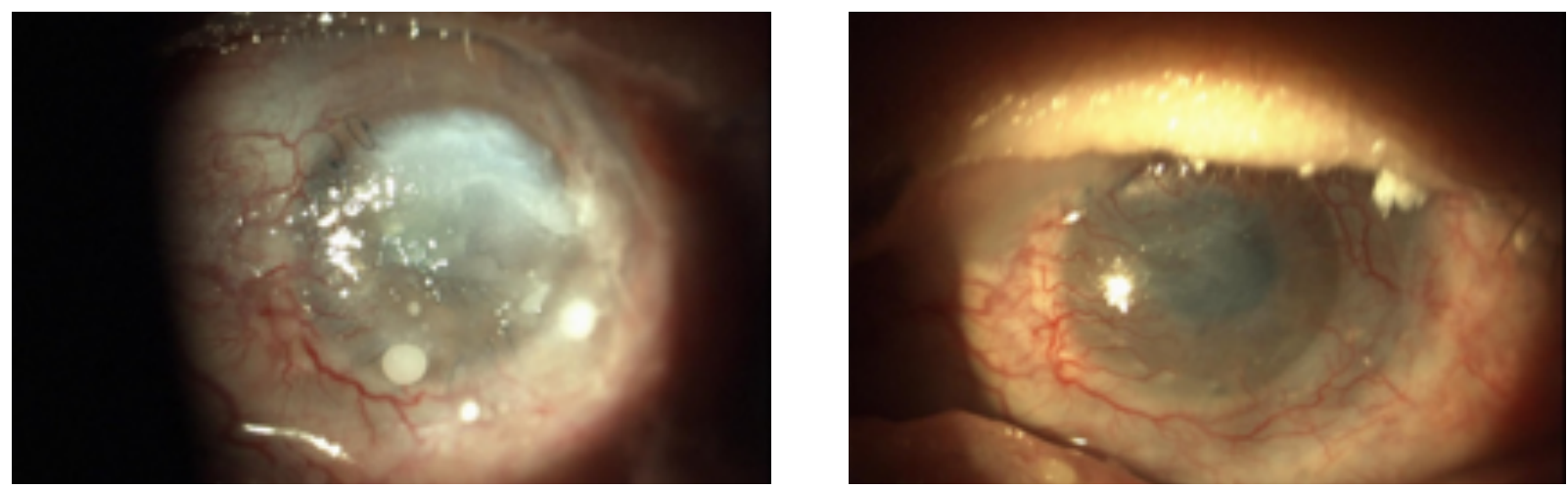

Figure 6. Preoperative image of an eye with total limbal stem cell deficiency and lid abnormality (a) caused by explosive burn and postoperative image at 2 years after transplantation of ex vivo cultivated limbal epithelial stem cells (b). Visual acuity improved from preoperative value of light perception to $10 \%$ postoperatively.

clinical work today are fibrin and amniotic membrane, although other potential carriers are also tested. Same methodology is theoretically applicable for patients with bilateral corneal burns, when LSC allografts obtained from a relative or unrelated donor are used; however, with much lower success rate and a negative impact of aggressive systemic immunosuppressive treatment. The effort is also made to grow LSC in a media completely free of any animal-derived products, and successful clinical results of such technique, using only autologous human serum as the only growth supplement are already reported ${ }^{26,27}$. Later on, oral mucosal epithelial cell and mesenchymal stem cell grafts have been tried, which is of special interest in cases of bilateral corneal burns where autologous grafts from the other healthy eye can't be obtained $^{28-31}$. The transplantation of bioengineered oral mucosal epithelium is also a good strategy in bilateral LSC deficiency; however further studies are required to optimize the culture conditions and visual outcome $\mathrm{e}^{32}$.
In our clinical study on cases with unilateral total and partial LSCD we have investigated whether transplantation of limbal stem cells alone (without subsequent corneal graft) may restore normal anterior surface and adequately improve vision. On this small number of eyes, we have seen that in case of normal lid morphology and function patients had total visual recovery and normal anterior surface and did not need another surgery - corneal graft. In one case of serious lid abnormality caused by explosive wound significant improvement in both anterior surface and visual acuity was achieved after one year, however another surgery in form of corneal graft may be needed for full visual recovery. If the disease is bilateral, other autologous stem cells, such as oral mucosal cells, orbital fat cells and mesenchymal stem cells, might be an option. Recent data from literature, analysing overall published results on LSCD treatment have shown that an "older" approach of grafting limbal stem cells from a healthy eye without their amplification ex vivo may be equally 
good, or even superior option of treatment ${ }^{33}$. In our opinion, since a larger stem cell graft has to be excised from a healthy eye with this approach, it is still questionable whether this may have consequences in a long run.

\section{CONCLUSION:}

In case of limbal stem cell deficiency (LSCD) best source of LSC is from the other uninjured eye with their multiplication by ex vivo cultivation. In eyes with normal lid function vision can be significantly improved by LSC graft alone, without any further need for subsequent corneal graft, which is not the case if serious lid abnormality is present.

\section{ACKNOWLEDGEMENT:}

This work has been supported by Croatian Science Foundation under the project IP-2016-06-6878, Custom Tailored Fibrous Scaffold Prototype for Tissue Cells Culture via Combined Electrospinning, COMBOELECTROSPUN.

\section{AUTHOR CONTRIBUTIONS:}

All authors listed have made a substantial, direct and intellectual contribution to the work, and approved it for publication.

\section{LITERATURE:}

1. Pellegrini G, Dellambra E, Golisano O, Martinelli E, Fantozzi I, Bondanza et al. p63 identifies keratinocyte stem cells. Proc Natl Acad Sci USA. 2001;98(6):3156-61. doi: 10.1073/pnas.061032098

2. Kenyon KR, Tseng SC. Limbal autograft transplantation for ocular surface disorders. Ophthalmology 1989;96(5):709-22.

3. Tsai RJ, Li LM, Chen JK. Reconstruction of Damaged Corneas by Transplantation of Autologous Limbal Epithelial Cells. N Engl J Med. 2000;343(2):86-93. doi: 10.1056/NEJM200007133430202

4. Schwab IR (1999) Cultured corneal epithelia for ocular surface disease. Trans Am Ophthalmol Soc. 1999;97:891-986.

5. Schwab IR, Reyes M, Isseroff RR. Successful transplantation of bioengineered tissue replacements in patients with ocular surface disease. Cornea. 2000;19(4):421-6.

6. James SE, Rowe A, Ilari L, Daya S, Martin R. The potential for eye bank limbal rings to generate cultured corneal epithelial allografts. Cornea. 2001;20(5):488-94.

7. Pellegrini G, Traverso CE, Franzi AT, Zingirian M, Cancedda R, De Luca M. Long-term restoration of damaged corneal surfaces with autologous cultivated corneal epithelium. Lancet. 1997;349(9057):9903. doi: 10.1016/S0140-6736(96)11188-0

8. Rama P, Matuska S, Paganoni G, Spinelli A, De Luca M, Pellegrini G. Limbal stem-cell therapy and long-term corneal regeneration. N Engl J Med. 2010;363(2):147-55. doi: 10.1056/NEJMoa0905955. Epub 2010 Jun 23.

9. Sangwan VS1, Basu S, Vemuganti GK, Sejpal K, Subramaniam SV, Bandyopadhyay S. et all. Clinical outcomes of xeno-free autologous cultivated limbal epithelial transplantation: a 10-year study. Br J Ophthalmol. 2011;95(11):1525-9. doi: 10.1136/bjophthalmol-2011-300352.

10. Rama P1, Bonini S, Lambiase A, Golisano O, Paterna P, De Luca M. et all. Autologous fibrin-cultured limbal stem cells permanently restore the corneal surface of patients with total limbal stem cell deficiency. Transplantation. 2001;72(9):1478-85.

11. Grueterich M, Espana EM, Tseng SC. Ex vivo expansion of limbal epithelial stem cells: amniotic membrane serving as a stem cell niche. Surv Ophthalmol. 2003;48(6):631-46.
12. Dekaris I, Gabrić N (2009) Preparation and Preservation of Amniotic Membrane. Dev Ophthalmol. 2009;43:97-104. doi: 10.1159/000223842. Epub 2009 Jun 3.

13. Tominac Trcin M, Dekaris I, Mijović B et al. Syntetic vs natural scaffolds for human limbal stem cells. Croat Med J. 2015 Jun 19;56(3):246-56.

14. Chen JJ, Tseng SC. Abnormal corneal epithelial wound healing in partial-thickness removal of limbal epithelium. Invest Ophthalmol Vis Sci. 1991;32(8):2219-33.

15. Dua HS, Joseph A, Shanmuganathan VA et al. Stem cell differentiation and the effects of deficiency. Eye(London) 2003;17(8):877-85. 16. Puangsricharern V, Tseng SC. Cytologic evidence of corneal diseases with limbal stem cell deficiency. Ophthalmology 1995;102(10):1476-85.

17. Lindberg K, Brown ME, Chaves HV et al. Towards therapeutic application of ocular stem cells. Investigated Ophthalmology and Visul Sciences 1993;34(9):2672-9.

18. Koizumi N, Inatomi T, Quantock AJ et al. Amniotic membrane as a substrate for cultivating limbal corneal epithelial cells for autologous transplantation in rabbits. Cornea 2000;19(1):65-71.

19. Meller D, Pires RT, Tseng SC. Ex vivo preservation and expansion of human limbal epithelial stem cells on amniotic membrane cultures. Journal of Ophthalmology 2000;86(4):463-71.

20. Sidney LE, Branch MJ, Dua HS et al. Effect of culture medium on propagation and phenotype of corneal stroma-derived stem cells. Cytotherapy 2015;17(12):1706-22. doi: 10.1016/j.jcyt.2015.08.003. 21. López-Paniagua M, Nieto-Miguel T, de la Mata A et al. Successful Consecutive Expansion of Limbal Explants Using a Biosafe Culture Medium under Feeder Layer-Free Conditions. Curr Eye Res 2016;2:111.

22. Shimazaki J, Aiba M, Goto E et al. Transplantation of human limbal epithelium cultivated on amniotic membrane for the treatment of severe ocular surface disorders. Ophthalmology 2002;109(7):1285-90. 23. Zakaria N, Koppen C, Van Tendeloo V et al. Standardized limbal epithelial stem cell graft generation and transplantation. Tissue Engineering Part C Methods 2010;16(5):921-7. doi: 10.1089/ten. 
TEC.2009.0634.

24. González S, Mei H, Nakatsu MN et al. A 3D culture system enhances the ability of human bone marrow stromal cells to support the growth of limbal stem/ progenitor cells. Stem cell research 2016;16(2):358-64. doi: 10.1016/j.scr.2016.02.018.

25. Bobba S, Chow S, Watson S et al. Clinical outcomes of xeno-free expansion and transplantation of autologous ocular surface epithelial stem cells via contact lens delivery: a prospective case series. Stem Cell research \& therapy 2015;6:23. doi: 10.1186/s13287-015-0009-1.

26. Pathak M, Cholidis S, Haug K et al. Clinical transplantation of ex vivo expanded autologous limbal epithelial cells using a culture medium with human serum as single supplement: a retrospective case series. Acta Ophthalmologica 2013;91(8):769-75. doi: 10.1111/j.17553768.2012.02521.x.

27. O'Callaghan AR, Morgan L, Daniels JT et al. Human-derived feeder fibroblasts for the culture of epithelial cells for clinical use. Journal of tissue engineering and Regenerative medicine 2016;11(6):52943. doi: 10.2217/rme-2016-0039.

28. Dobrowolski D, Orzechowska-Wylegala B, Wowra B et al. Cultivated Oral Mucosa Epithelium in Ocular Surface Reconstruction in Aniridia Patients. Biomed Research International 2015;281870. doi: 10.1155/2015/281870. Epub 2015 Sep 16.
29. Utheim TP. Concise review: transplantation of cultured oral mucosal epithelial cells for treating limbal stem cell deficiency-current status and future perspectives. Stem cell 2015;33(6):1685-95. doi: 10.1002/stem. 1999

30. Dhamodaran K, Subramani M, Jeyabalan N et al. Characterization of ex vivo cultured limbal, conjunctival, and oral mucosal cells: A comparative study with implications in transplantation medicine. Molecular Vision 2015;31;21:828-45. eCollection 2015.

31. Holan V, Trosan P, Cejka C et al. A Comparative Study of the Therapeutic Potential of Mesenchymal Stem Cells and Limbal Epithelial Stem Cells for Ocular Surface Reconstruction. Stem Cells Transl Med 2015;4(9):1052-63. doi: 10.5966/sctm.2015-0039.

32. Priya CG, Arpitha P, Vaishali S et al. Adult human buccal epithelial stem cells: identification, ex-vivo expansion, and transplantation for corneal surface reconstruction. Eye (London) 2011;25(12):1641-9. doi: 10.1038/eye.2011.230.

33. Shanbhag SS, Nikpoor N, Rao Donthineni P et al. Autologous limbal stem cell transplantation: a systematic review of clinical outcomes with different surgical techniques. Br J Ophthalmol. 2019 May 22. pii: bjophthalmol-2019-314081. doi: 10.1136/bjophthalmol-2019-314081. [Epub ahead of print] 